\begin{tabular}{c|l|l|l|l}
\hline Volume 1 & Issue 2 & August (2020) & DOI: 10.47540/ijsei.v1i2.8 & Page: $73-78$ \\
\hline
\end{tabular}

\title{
Socio Cultural Study of Temanggung Tobacco Farmers in the Global Trans
} Era

\author{
Ali Imron ${ }^{1}$, Muhammad Niky Nur Komaruddin ${ }^{2}$, Eri Setyo Darmawan ${ }^{3}$, Novita Ayu Kurnia \\ Illahi $^{4}$ \\ ${ }^{1,2,3,4}$ Universitas Negeri Surabaya, Surabaya, Indonesia
}

Corresponding Author: Ali Imron; Email: aliimron@unesa.ac.id

A R T I C L E I N F O
$\begin{aligned} & \text { Keywords: Culture; Temanggu } \\ & \text { Tobacco. }\end{aligned}$
$\begin{array}{ll}\text { Received } \quad: 22 \text { May } 2020 \\ \text { Revised } & : 24 \text { June } 2020 \\ \text { Accepted } & : 08 \text { August } 2020\end{array}$

A R T I C LE I N F O

Keywords: Culture; Temanggung;

Received : 22 May 2020

Revised : 24 June 2020

Accepted :08 August 2020 \section{ia}


Tobacco for the Temanggung District community is not only a matter of farming. Tobacco has an important role in the social structure of society. Tobacco has become an inseparable part of daily life. One of the best tobacco producers in Indonesia, are Dusun Lamuk Legok, Legoksari Village, Tlogomulyo Sub-District, where tobacco is represented as a form of community cultural identity. Planting tobacco for the people of Lamuk Legok, Legoklsari Village is a form of preservation of their noble culture, from pre-planting to harvest, all of which cannot be separated from the value of noble culture.

These cultures include Among tebal as a sign of the beginning of the tobacco planting season (Temanggungkab, 2017). In the tobacco season also follows the Pranoto Mongso calendar and also the Aboge as a reference for determining when to plant and also harvest. Tobacco has become a part of the life of the people of Legoksari. Until now the Tobaku plantation sector is still the main livelihood of the people of Legoksari Village.

Tobacco researches focus more on aspects of the impact of anti-tobacco policies, trade governance, and risks faced by farmers. However, researches on tobacco as a cultural product have not yet been carried out. Rahman and Slamet's (2015) research on the impact of tobacco control policies due to price instability caused by high farmer production results and is not matched by absorption of smallholder tobacco products in the tobacco processing industry. Furthermore, a research on tobacco trading in Temanggung District by Pamungkas and Rusjdijati (2015) reviews the actors who are entitled to determine the quality of tobacco, it is graders. Farmers can't determine the quality of tobacco so that the welfare of farmers is getting worse. The study of the tobacco farmers risk chain in Temanggung District shows the risks that must be faced by farmers are weather, access to capital, price and quantity (Muchfirodin, et al., 2013).

Departing from the study of tobacco, no one has seen tobacco from the socio-cultural aspects. Therefore, this research focuses on the sociocultural aspects of tobacco farmers in Lamuk Legok, Lekoksari Village, Tlogomulyo SubDistrict, Temanggung District in the face of globalization.

\section{MATERIALS AND METHODS}

This research used a qualitative method. The approach used in this research was ethnography. The ethnographic approach aimed to study the social life and culture of the community by participating in the daily lives of its people.

This research took place in the Lamuk Legok, Legoksari Village, Tlogomulyo Sub-District, Temanggung District. The research location was chosen because the residents of Lamuk Legok see tobacco as not only a plant to be cultivated. Tobacco has cultural value for the people. Many cultural rituals are per-formed before planting to harvest. The beginning of planting tobacco is determined by the Javanese calendar, Pranoto Mongso. Besides that, Lamuk Legok is also the best tobacco producer, Srinthil.

The data collection was carried out in two ways, they are primary data and secondary data extraction. Primary data were obtained through participant observation and in-depth interviews. While secondary data obtained from statistical data, journal articles, and reference books that are relevant to the focus of research.

Data were then analyzed using the Spradley model. There are four types of analysis in the Spradley model (Emzir, 2012); (1) domain analysis, i.e. find categories that are carried out by giving general and detailed questions, (2) taxonomic analysis, which is to describe in more detail the domains that have been found, (3) componential analysis, which is looking for specific characteristics in each internal structure by contrasting between elements, and (4) analysis of cultural themes, that is, looking for relationships between domains and relationships between whole which are then expressed into themes that are in accordance with the focus and sub-focus of research. The validity technique uses triangulation method based on the source.

\section{RESULTS AND DISCUSSION \\ Culture of Tobacco Farmers}

Tobacco began to be known by the people of the Temanggung District since 1746, brought by the Dutch East Indies Government (Widiyanto et al, 2010) and became the main livelihood of the Temanggung residents. Farmers are closely related to the countryside and characterized by a subsistence economy. On the other hand, farmers 
also have a culture contained in it. Culture is a system (of socially derived behavioral patterns) that works to connect human communities with their ecological environment (Kesing, 2016). One of them is tobacco farmers in Legoksari Village, which has a culture in its agricultural activities. The culture can be categorized into three parts.

First, pre-planting culture. Before planting tobacco, farmers knew the terms siti, wiji, wanci and permadi. Siti is a soil element that must be considered because the slope level is more than $15 \%$ and the soil texture is dominated by gravel. Farmers use a terracing system to prevent landslides. Wiji is a tobacco seed, farmers must ensure that the seeds used must be the best, one of which is to work together with the Ministry of Agriculture's Hatchery Center to develop better Kemloko tobacco seeds. Wanci is tobacco planting time which is in accordance with Javanese calendar calculation of Pranoto Mongso. Permadi is a tobacco treatment that must be maximized to get quality tobacco products. Prasetyo's research (2016) on tobacco productivity shows the level of soil density also affects productivity and the level of erodibility affects the level of tobacco quality index. The higher the erodibility, the higher the tobacco quality index.

Before entering the planting time and important days in tobacco farming, farmers have time restrictions that should not be violated. If violated, it will get a yield that is not optimal. The first taboo is a studio year or weton year. Farmers use the Aboge calendar which has an eight year cycle.

Table 1. Aboge Calendar

\begin{tabular}{|l|l|}
\hline \multicolumn{1}{|c|}{ Year } & \multicolumn{1}{c|}{ Weton of Year } \\
\hline Alip & Rabu Wage \\
\hline Ehe & Ahad Pon \\
\hline Jim Awal & Jum'at Pon \\
\hline Je & Selasa Pahing \\
\hline Dal & Sabtu Legi \\
\hline Be & Kamis Legi \\
\hline Wawu & Senin Kliwon \\
\hline Jim Akhir & Jum'at Wage \\
\hline
\end{tabular}

Every year there must be a weton which is unyielding. Second, geblak or the time of death of a parent. Third, dino which refers to the sum of weton of each tobacco farmer. Finally, pupak puser which means the release of the umbilical cord of each baby. The day that is not recommended for planting tobacco is done to honor the day that has been used by Waton of the year, geblak, apese, and pupak puser. Farmers also use the standard of Javanese culture in counting the days of each cultural ritual.

Table 2. Benchmark and Pasaran of Neptu

\begin{tabular}{|c|c|c|c|}
\hline Day & Neptu & Pasaran & Neptu \\
\hline Minggu & 5 & Legi & 7 \\
\hline Senin & 4 & Pon & 5 \\
\hline Selasa & 3 & Pahing & 9 \\
\hline Rabu & 7 & Kliwon & 8 \\
\hline Kamis & 8 & Wage & 4 \\
\hline Jum'at & 6 & & \\
\hline Sabtu & 9 & & \\
\hline
\end{tabular}

Second, planting culture. Cultivation culture is carried out by tobacco farmers in the early days of land cultivation and in the beginning of planting tobacco seeds. The traditional ceremony that was carried out in the early days of processing land in tobacco cultivation was nyecel. The meaning of scolding is gratitude to the almighty God. Planting culture that is carried out by the community after implementing lekas macul or nyecel is lekas tebal. The word tebal is the term for growing tobacco, so that it can be interpreted that thick is a tradition that is carried out when it will start planting tobacco. In the fast ritual there is a prayer in Javanese that is offered by the community.

"Niat ingsun arep titip nandur mbako ono ing tegal kene

Mugi Gusti Allah maringi pitulungan, mbakone lemu

Adoh seko panggodo pengencono.

Nyuwun berkahe poro Nabi, poro Wali

Nyuwun berkahe Ki Ageng

Mangkukuhan, Panembahan Tegil

Mbesok mbakonepayu larang tak upahupahi juadah pasar ketan salak."

"My intention is to plant tobacco in this field. May God give help, the tobacco is fertile, Away from distractions and threats.

Please bless (also) from the Prophet, the Trustees,

Please bless Ki Ageng Mawaruhan Panembahan Tegil.

(If) I sell high-priced tobacco, I will present juadah pasar ketan salak”, 
Third, harvest culture. Tobacco plants have a growth period of seven months. Tobacco harvesting period in Legoksari Village is generally carried out in August and September. At the beginning of the harvest, tobacco is known as miwiti, which is a cultural ritual carried out to start the first pick of tobacco leaves in the field. The implementation of Miwiti should not be concurrent with the prohibition of four big days, they are sangar tahun, geblak, apese, and pupak puser.

Furthermore, the tungguk ritual is held in the middle of the harvest. This is because if it is carried out at the beginning of the harvest it cannot be carried out because the main focus of all villagers is the Tobacco harvest. One of the hallmarks of the stump ritual is the kapuroto rice which is spread to the four cardinal points in the tobacco fields as a sign of turning down of all sorts of danger.

\section{Philosophical Meaning}

Every part of the ritual carried out by tobacco farmers in Legoksari Village cannot be separated from the philosophical meaning contained therein. First, jenang abang putih, in general can be interpreted as red is the earth and white is the sky. Specifically, red from maternal blood, white from father's blood. The two elements then become humans, so they are symbolized by red and white jenang. This implies that humans must remember their origins. Humans are born from red and white.

Second, sego bakar cambah pethek, composed of several ingredients, they are shrimp paste and fish. Fish that live in the sea symbolize the mood, his heart as wide as the ocean. Seng lego legowo. It is sprouts and legumes are plants that are easy to grow. Chili symbolizes the spiciness of life and behavior. In achieving the ideals must be firm and brave to face the red feeling. Shallot means to be brave to bleed. Something bold desire, but must be based on garlic. Garlic means purity. Burned rice means a strong determination that is made to cone because it is headed for one goal. Tobacco farmers must have resilience in the face of heat and rain.

Third, tumpeng cemeng, it is tumuju mareng pemaleh (towards the almighty). The sharp shape of a cone is like a meditating person's hand, where the right and left hands are fused. The meaning is a combination of the nature of God and humans.

Fourth, jaddah or ketan rice symbolizing rumakete ing seduluran or close brotherhood. Tobacco cannot be processed alone. There are several components that cannot be produced in Legoksari Village, such as tobacco baskets, banana trunks for tobacco and rigen covers or a place for drying tobacco. Tobacco involves various parties; its components are many and become one entity. Therefore, symbolized by ketan rice.

Ketan rice has a sticky texture. If it is added with a mixture, it will taste delicious. This means that in socialization there must be a good sense. While red jaddah has a sweet taste, as does the sweetness of community or business. There was nothing bitter at the offering ceremony. If anyone forgets the offerings, they have been replaced using bananas, which are given coins, which means that if there are deficiencies, they can look for themselves.

\section{Strategies to Maintain the Culture of Tobacco Farmers}

Tobacco has a strategic value in the Village of Legoksari. The entire family's profession is as a tobacco farmer and the land in the Legoksari Village in the dry season can only be planted with tobacco. In addition, there are sublime cultural traditions that have existed in the Legoksari Village since ancient times. Broadly speaking, the strategy undertaken by the farmers of Legoksari Village is divided into two they are cultural strategy and legal strategy. Cultural strategies are carried out by giving an understanding of tobacco to children and grandchildren since childhood. Directly invite the tobacco culture ritual process.

At the age of the child, they began to be introduced and invited to watch the process of resistance, then given an understanding of the culture of tobacco farmers gradually when they entered adolescence. When they reach adulthood, they can practice the entire culture in the Village of Legoksari. The entire community of Legoksari Village works as a tobacco farmer so that this facilitates the regeneration process. This phenomenon illustrates that what was conveyed by Koning (2004), White \& Margiyatin (2009), and Naafs (2012), which revealed that the younger generation in rural Indonesia was not interested in agriculture, apparently was not found in Legoksari Village.

Another cultural strategy is to use the Srinthil Dance media. Srinthil dance is a representation of the daily life of tobacco farmers in the Legoksari Village in managing tobacco. The philosophical aspects of the Srinthil dance are the cultivation and 
culture of tobacco. In the Srinthil Dance the threats in the form of pests and anti-tobacco parties are explained. The end of the Srinthil Dance is the synergy between tobacco farmers, traditional leaders, and dampo awang which leads to the welfare of tobacco farmers. Juragan dampo awang is a trusted figure as the person who started the trading system in Temanggung.

Through Srinthil Dance, tobacco farmers introduce their culture to the world and as one of the farmers' regeneration strategies so as not to lose their cultural identity. Srinthil dance proves that the values of local wisdom are not obsolete and outdated values, but values that can synergize with universal values and modern values brought by globalization (Safril, 2011).

Second, the legal strategy is carried out by the farmers of Legoksari Village in an effort to obtain legal protection against tobacco, especially Srinthil tobacco. Legal strategy is performed to show the existence of tobacco farmers. Srinthil Tobacco is registered in the Intellectual Property Rights field of Geogra-phical Indication with Registration Number: ID G 000000027 and registered on May 13, 2014 at the Ministry of Law and Human Rights of the Republic of Indonesia. Purpose Legal protection of intellectual property is intended so that those who have the right can exploit their wealth with a sense of security and comfort (Tanu, 2015).

Through the Indonesian Tobacco Farmers Association (APTI), tobacco farmers also submit a Draft Law on Tobaccory which aims to protect and improve the welfare of tobacco farmers. Until now, the Tobacco Bill is still in the DPR RI National Legislation Program. One of the considerations proposed in the Tobacco Draft Bill as written in point (A) is to consider tobacco as Indonesia's biological wealth and cultural heritage. Article 1 point 6 also states that processed tobacco products in the form of kretek are also included in the Indonesian cultural heritage (Draft Law on Tobaccory, 2016). Another important point of the Revised Draft Law is that it is limited to the import quota limit of $20 \%$ of total production capacity. This is aimed at protecting tobacco farmers from the increasingly massive influx of imported tobacco.

\section{Conclusion}

Tobacco has an important role in the dynamics of social and cultural life in the Village of Legoksari. First, it has economic value, especially Srinthil tobacco which can only be grown in Legoksari Village. Second, the function of culture, because in the process of tobacco cultivation there is a cultural dimension that accompanies it. The noble culture must be maintained as a form of preserving the noble culture of the nation. Culture and cultivation are two inseparable entities, especially for tobacco farmers in Legoksari Village.

\section{REFERENCES}

Abihisa, D.M. dkk. (2011). Membunuh Indonesia: Konspirasi Global Penghancur Kretek. Jakarta: Kata-kata.

Badan Perencanaan dan Pembangunan Daerah Temanggung. Rencana Induk Pertembakauaan Kabupaten Temanggung. (Online). (bappeda.temanggung.go.id. Diakses 18 Oktober 2017).

Damhuri, E. (2017). Kesejahteraan Petani Tembakau. (Online).

(https://www.republika.co.id. Diakses 1 Agustus 2018).

Direktorat Jendral Perkebunan. (2017). Statistik Perkebunan Indonesia Komo-ditas Tembakau 2015-2017. Jakarta: Dirjenbun.

Emzir. (2012). Analisis Data: Metodologi Penelitian Kualitatif. Jakarta: Raja-Grafindo Persada.

Gerintya, S. (2017). Seberapa Banyak Rokok Sumbang Pemasukan Kas Negara?. (Online). (https://tirto.id/. Diakses 1 Agustus 2018).

Haryanto, A. (2017). Faisal Basri Pertanyakan Sikap Kementan Dukung RUU Tembakau. (Online). (https://tirto.id. Diakses 20 Oktober 2017).

Kesing, M.R. (2016). Teori-teori tentang budaya. Jurnal Antropologi, 2(1): 52-64.

Kusuma, H. (2017). Impor Tembakau RI Paling Banyak Dari China. (Online). (https://finance.detik.com/. Diakses 7 Agustus 2018).

Media Center Temanggung. (2017). Dusun Lamuk Legok Gelar Kirab Sesaji Bhumi Sakti. (Online).

(http://mediacenter.temanggungkab.go.id. Diakses 2 Desember 2017). 
Muchfirodin, M., dkk. (2015). Supply chain risk management on tobacco commodity in Temanggung, Central Java: case study at farmers and middlemen level. Agiculture and Agricultural Science Prosedia, 3(1): 235240.

Naafs, S. (2012). Generasi antara: refleksi tentang studi pemuda Indonesia. Jurnal Studi Pemuda. 1(2): 35-43.

Pamungkas, K.S. dan Retno R. 2015. Persepsi petani tentang tata niaga tembakau di Kabupaten Temanggung. The 2nd University Research Coloquium, 78-89.

Prasetyo, A. dkk. (2016). Kajian produktivitas dan mutu tembakau Temanggung berdasarkan nilai indeks erodibilitas dan kepadatan tanah. Jurnal Tanah dan Sumberdaya Lahan. 3(2): 85-93.

Widiyanto, dkk. (2018). Strategi nafkah rumah tangga petani tembakau di lereng Gunung Sumbing. Sodality. 4(1): 58-65.

Safril, A.M. (2011). Revitalisasi identitas kultural Indonesia di tengah upaya homogenisasi global. Jurnal Global \& Strategis, 1(1): 7585.

Tanu, H.A. (2015). Urgensi perlindungan hak kekayaan intelektual dalam era per-dagangan bebas. Lex Jurnalica. 12(3): 105-117. 